\title{
Egg Development and Early Life History of Korean Endemic Species Korean Spotted Sleeper, Odontobutis interrupta (Pisces: Odontobutidae)
}

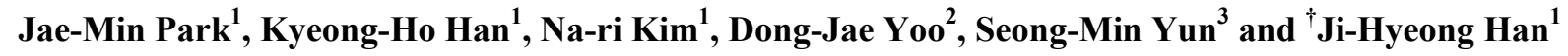 \\ ${ }^{1}$ Dept. of Aqualife Science, Chonnam National University, Yeosu 550-749, Korea \\ ${ }^{2}$ Gyeongsangbuk-Do Fisheries Resources Development Institute, Yeongdeok 766-852, Korea \\ ${ }^{3}$ Gyeongsangbuk-Do Research Center for Freshwater Fishes, Uljin 767-873, Korea
}

\begin{abstract}
The egg development and early life history of Korean spotted sleeper, Odontobutis interrupta which is Korean endemic species from Sora-choen was investigated. The Korean spotted sleeper were caught at Sora-myeon, Yeosu-si, Jeollanamdo, from Korea at May in 2014. The fertilized eggs were $4.23 \pm 0.05 \mathrm{~mm}$ in long diameter and had oil globules. Hatching time of the embryo began about $442 \mathrm{hr} 14 \mathrm{~min}$ after fertilization under water temperature of $19.5^{\circ} \mathrm{C}$. The newly hatched larvae were $4.27 \pm 0.35 \mathrm{~mm}$ in total length and their anus were not yet opened. 3 days after hatching postlarvae was measured $6.20 \pm 0.11 \mathrm{~mm}$ in total length. 10 days after hatching postlarvae was measured $6.69 \pm 0.14 \mathrm{~mm}$ in total length.
\end{abstract}

Key words : Early life history, Juvenile, Larvae, Odontobutis interrupta

\section{INTRODUCTION}

Odontobutis interrupta is one of freshwater fishes and belongs to the Perciformes, Odontobutidae; globally, there are 4 genera and 6 species reported whilst 2 genera and 4 species were found in Korea including O. interrupta, Micropercops swinhonis, O. platycephala, and O. obscura of these, O. interrupta, a Korean native species, has been known to inhabit in rivers that flow into the Yellow sea and the South sea of Korea (Kim et al., 2005).

Studies regarding early life history of fishes have been being widely utilized as important data 1) to investigate conservation of endangered species and their breeding ecology, and 2) to understand biological features of species (Blaxter, 1974; Seo et al., 2006). Amongst four species of
Odontobutidae, there are few investigations regarding early life history of Micropercops swinhonis and O. platycephala (Choi \& Jin, 1977; Kim \& Kim, 1994; Kim \& Kim, 1995; Kim \& Kim, 1996); in South Korea, multiple studies investigated the Odontobutidae in reference to their genetic distribution, comparisons of pigments constituents (Kim et al., 1998), reproductive steroids (Lee \& Yang, 1998) and changes in hormone levels (Lee, 1998) while international studies have elucidated their spawning activities (Mashiko, 1976), distribution of Odontobutidae fishes (Iwata et al., 1985), larval development of $O$. obscura (Iwata et al., 1988), genetic comparisons (Sakai et al., 1993), genetic distribution patterns (Sakai et al., 1999), embryo development of $O$. hikimius (Doi \& Aoyama, 2006), migration of 2 species of Eleotris (Meda \& Tachihara,

\footnotetext{
Manuscript received 17 November 2014, Received in revised form 24 November 2014, Accepted 26 November 2014

${ }^{\dagger}$ Corresponding Author : Ji-Hyeong Han, Dept. of Aqualife Science, Chonnam National University, Yeosu 550-749, Korea. Tel. : +82-61-659-7163, Fax : +82-61-685-9073, E-mail : gost016803@naver.com

This is an Open Access article distributed under the terms of the Creative Commons Attribution Non-Commercial License (http:// creativecommons.org/licenses/by-nc/3.0) which permits unrestricted non-commercial use, distribution, and reproduction in any medium, provided the original work is properly cited.
} 
2005), and larval development of Perccottus glenii (Voskoboinikova \& Pavlov, 2006).

The Sora-creek, where Odontobutidae interrupta inhabit at, is the second class of local river located in the middle of Yeosu peninsula, Korea. This creek has been being used for both water for living as well as agricultural water however population of $O$. interrupta is being gradually decreased due to influx of pesticides and sewage in busy farming seasons there by aggravating pollution (Lee et al., 2004). In the present study, we investigated egg development and early life history of $O$. interrupta hence providing basic data of taxonomic study.

\section{MATERIALS AND METHODS}

\section{Management of eggs}

Eggs used in the present study were obtained from the Sora-creek, located in Sora-myeon, Yeosu city, Jeollanamdo, Korea from March $1^{\text {st }} 2014$ through May 31 2014. All obtained eggs were naturally spawned under rocks in the creek (Fig. 1). Upon collected, eggs were translocated and maintained into a square glass aquarium $(50 \times 20 \times 15 \mathrm{~cm})$ in the lab. The water temperature for rearing was $18.5-20.5^{\circ} \mathrm{C}$ (mean $19.5^{\circ} \mathrm{C}$ ) and the one third of water was changed daily. The eggs were sterilized using formalin (100 ppm) over 15 mins in order to eliminate parasites present on the surface of eggs while perished eggs in their development

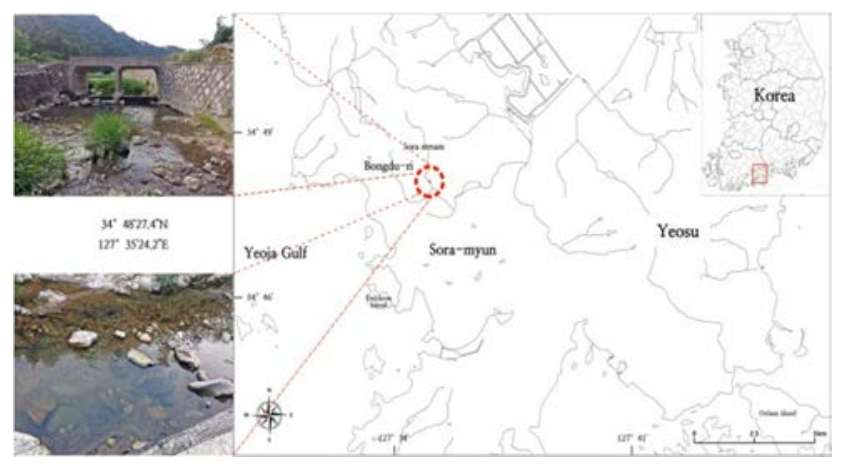

Fig. 1. Map showing the studies sites of Korean spotted sleeper, Odontobutis interrupta. were removed.

\section{Process of egg development}

In order to monitor processes of egg development, a total of 50 eggs were randomly retrieved and then placed in a $500 \mathrm{~mL}$ glass beaker. A multi-purpose projector (Nikon JP V-12B, Japan) was utilized in order to measure yolk absorption as well as sizes of eggs up to $0.01 \mathrm{~mm}$. A stereoscopic microscope (Nikon JP SMZ800, Japan) was used for observation and photography.

\section{Morphological development of larvae}

Upon hatched out, larvae were accommodated in a square glass chamber $(50 \times 20 \times 15 \mathrm{~cm})$ and raised in a pond culture system with gentle aeration. On day 6 of hatching, larvae were fed with brackish water rotifers (Brachionus rotundiformis; $10-15$ rotifers per $\mathrm{mL}$ concentration) and $2-3$ artemia (nauplius of Artemia sp.) were mixed with rotifers from day 8. For monitoring morphological development processes, 10 hatched larvae were removed daily and then anesthetized using tricaine methanesulfonate (MS-222, Sandoz, USA) under anesthesia, yolk and parts of fish body were observed and measured up to $0.01 \mathrm{~mm}$ with an aid of a multi-purpose projector as well as stereoscopic microscope. Stages of morphological development were defined as suggested in Rusell (1976).

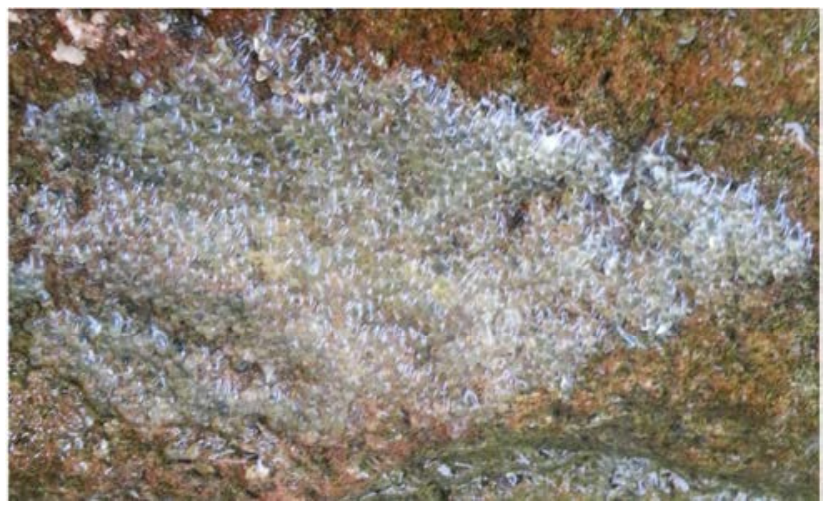

Fig. 2. The egg mass of Korean spotted sleeper, Odontobutis interrupta. 


\section{RESULTS}

\section{Spawning ground and allomothering}

The most common place for spawning of $O$. interrupta was found to be in middle of rocky creek where gravel and sand were laid on the bottom with gentle current. The spawning period was from late March through May while the water level was in between $50-100 \mathrm{~cm}$ during this period the water temperature was ranging from $14.5-18.5^{\circ} \mathrm{C}$ (mean water temperature: $16.0^{\circ} \mathrm{C}$ ). Eggs were placed on the bottom of rocks $(30 \times 100 \mathrm{~cm})$ forming a layer and male fishes were protecting eggs against other fishes. These male fishes were providing oxygen using pectoral and caudal fins and eggs perished or stopped developing were removed with the mouth.

\section{Morphology of eggs}

Oval shaped eggs were sticky der mesal, and the long axis diameter and short axis diameter were 4.15-4.27 mm (mean $4.23 \pm 0.05 \mathrm{~mm}$ ) and 1.65-1.85 mm (mean $1.72 \pm$ $0.10 \mathrm{~mm})$, respectively. The size and numbers of oil droplets were ranging $0.05-0.13 \mathrm{~mm}$ (mean $0.08 \pm 0.03$ $\mathrm{mm}$ ) and 235-248 eggs, respectively. It was observed that the bottom of eggs was fixed with sticky filaments and separating lines of eggs were found per degree of development on the same spawning spot; there were approximately 810-828 eggs per each egg line (Fig. 2).

\section{Development processes of eggs}

The eggs reached to the 2 cell stage (Fig. 3A) and then four blastomeres were divided into 8 after $2 \mathrm{hrs}$ and 13 mins from the 2 cell stage to reach the 8 cell stage (Fig. 3B). After 4 hrs and 22 mins from the 2 cell stage, the egg was reached to 16 cell stage, After $5 \mathrm{hrs}$ and $20 \mathrm{mins}$ from the 32 cell stage (Fig. 3C). After $7 \mathrm{hrs}$ and $20 \mathrm{mins}$ from the 2 cell stage, the egg was reached to morula stage (Fig. 3D), and subsequently to the blastula stage after $19 \mathrm{hrs}$ and
7 mins from the 2 cell stage (Fig. 3E). After 24 hrs and 22 mins later, one third of yolk was covered to reach early gastrula stage (Fig. 3F). The embryo was formed after 53 hrs and 5 mins after the 2 cell stage (Fig. 3G) whilst the Kuffer's vesicles were formed on tails after $58 \mathrm{hrs}$ and 5 mins (Fig. 3H).

Optic vesicles were formed after $63 \mathrm{hrs} 32 \mathrm{~min}$ and Kuffer's vesicles were disappeared. In this, 2 myotomes were found as well (Fig. 3I). After $76 \mathrm{hr}$ and $31 \mathrm{~min}$, a total of 9 myotomes formed (Fig. 3J), and the caudal part was separated from the yolk after $93 \mathrm{hrs}$ and $3 \mathrm{mins}$ from the 2 cell stage. In this time, the numbers of myotomes were found to be 22 (Fig. 3K). After $109 \mathrm{hrs}$ and $23 \mathrm{~min}$ from the 2 cell stage, eye lenses were developed, brain was formed, and myotomes were increased up to 31 . The heart beat was shown with a rate of 50-56 per minute (Fig. 3L). After $166 \mathrm{hrs}$ and $23 \mathrm{~min}$, melanophores were precipitated and prototype of pectoral fins were formed; in addition membranous $\mathrm{f}$ caudal fins were also found (Fig. 3M). Blood from the heart flowed along the yolk to the basal part of caudal fin after $263 \mathrm{hrs}$ and 3 mins from the 2 cell stage.

The caudal fin was differentiated into the fan-shape (Fig. $3 \mathrm{~N})$. After $319 \mathrm{hr}$ and $3 \mathrm{~min}$ from the 2 cell stage, the lower jar started developing to open mouth while crystalline lenses were formed on eyes melanophores were precipitated with a shape of tree branch were precipitated on the basal parts of head and caudal fin (Fig. 3O).

Subsequently, further melanophores were precipitated with a shape of tree branch on the middle part of the body after $359 \mathrm{hr}$ and $8 \mathrm{~min}$ from the 2 cell stage and a total of 8 stems were developed on the caudal fin (Fig. 3P). After $402 \mathrm{hrs}$ and $11 \mathrm{mins}$, melanophores were precipitated on the upper part of yolk with a shape of tree branches.

In the mean time, the rate of branchial respiration was increased up to 100-102 times per minute whilst the tail was elongated to the front of head, indicating that eggs 


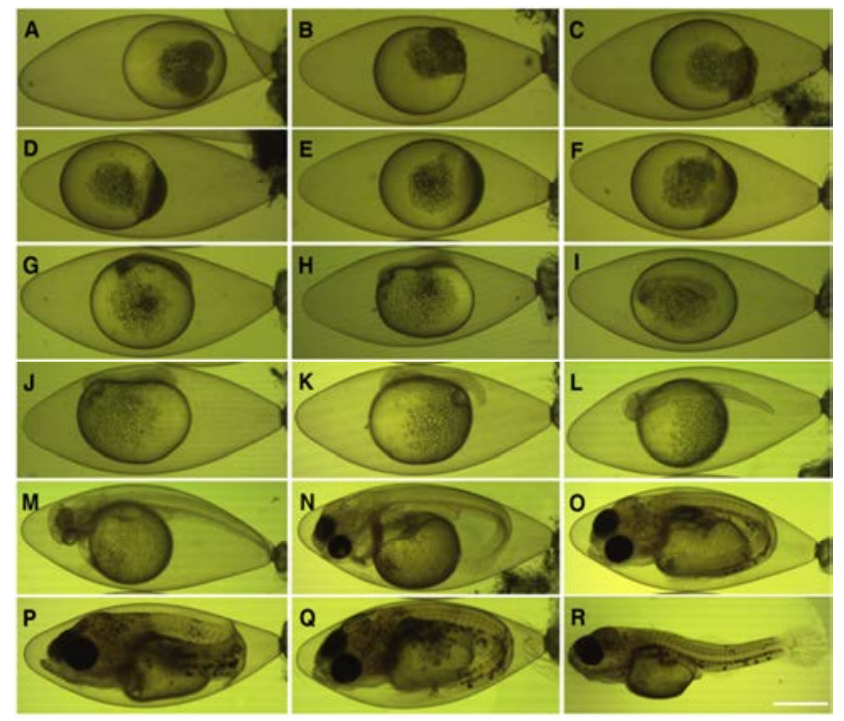

Fig. 3. The egg development of Korean spotted sleeper, Odontobutis interrupta. A: 2 cells; B: 8 cells, $2 \mathrm{hr}$ 13 min; C: 16-32 cells, 5 hr 20 min; D: Morula, 7 hr 20 min; E: Blastula, 19 hr 7 min; F: Gastrula, 24 hr $22 \mathrm{~min}$; G: Embryo of developing, 53 hr $5 \mathrm{~min}$; $\mathrm{H}$ : Appearance of Kuffer's vesicle, $58 \mathrm{hr} 5 \mathrm{~min}$; I: 2 myotomes stage, $63 \mathrm{hr} 32 \mathrm{~min}$; 9 myotomes stage, $76 \mathrm{hr} 31 \mathrm{~min}$; K: 22 myotomes stage, $93 \mathrm{hr} 3$ min; L: Brain of developing and heart beating, 109 hr 32 mins; M: Appearance of melanophores in the eyes, $166 \mathrm{hr} 32 \mathrm{~min}$; N: Otolith of developing, 263 hr 3 min; O: Open the mouth, 319 hr 3 min; P: Appearance of melanophores in the embryo, $359 \mathrm{hr}$ 8 min; Q: Embryo just before hatching, 402 hr 11 min; R: Hatching larvae. Scale bar $=1.0 \mathrm{~mm}$.

were about to be hatched (Fig. 3Q). The head started breaking through the upper membrane of eggs in order to hatch after $442 \mathrm{hr}$ and $14 \mathrm{~min}$ from the 2 cell stage (Fig. $3 R)$.

\section{Morphological development of larvae and juvenile} fishes

Right after hatching, early larvae had the total length ranging 3.87-4.53 mm (mean $4.27 \pm 0.35 \mathrm{~mm}$; $\mathrm{n}=10$ ) with opened mouth. The anus was not opened yet while yolk was present.
The air bladder was developed and melanophores were present on the upper part of head and basal part of tail with a shape of tree branches. Membranous tails were split into dorsal and ventral fins. The numbers of stems in dorsal and caudal fins were 6 and $11(6+5)$, respectively. The upper terminal of vertebrae was flexed to $45^{\circ}$. In this, the numbers of vertebrae bones were $28(11+17)$ while the anus was placed on the position of $48.2 \%$ of the total length (Fig. 4A).

On day 3 of hatching, early larvae had had the total length ranging 6.12-6.34 $\mathrm{mm}$ (mean $6.20 \pm 0.11 \mathrm{~mm}$ ) with opened anus. Melanophores were present from the upper anus through the end of tail in three horizontal stripes. The dorsal fin was split into two and the first dorsal fin had spiny rays. In contrast the second dorsal fin had 7 soft rays whilst 11 stems were formed on the pectoral fin. Three stems were formed on the ventral fin and the caudal fin had 14 stems $(6+8)$. In this period, the number of vertebrae bones were $31(15+16)$ and the anus was present on the position of $46.1 \%$ of the total length of body (Fig. 4B).

On day 6 of hatching, the total length was $6.25-6.56$ $\mathrm{mm}$ (mean $6.43 \pm 0.16 \mathrm{~mm}$ ) and all yolk was completed absorbed. Melanophores were precipitated on the gastrointestinal tract in a shape of tree branches. There were seven spiny rays were present on the first dorsal fin while tips of $4^{\text {th }}$ through $7^{\text {th }}$ soft rays were split in to the Y-shape. In this period, the anus was placed on the position of $48.1 \%$ of the total length of body (Fig. 4C).

On day 10 of hatching, postlarvae had the total length of 6.52-6.77 mm (mean $6.69 \pm 0.14 \mathrm{~mm}$ ) with increased number of stems on the pectoral fin 15 stems, there were 4 stems present on the ventral fin as well. The head size seems lightly big considering the size of body and placed on the position of $91.4 \%$ of the total length of body. The soft rays were increased up to 9 in the second dorsal fin and the anus was positioned on the position of $48.8 \%$ of the total length (Fig. 4D). 
After 13 days from hatching, postlarvae had the total length ranging 6.84-7.38 $\mathrm{mm}$ (mean $7.11 \pm 0.26 \mathrm{~mm}$ ) and the numbers of stems on the caudal fin were increased up to $15(8+7)$, there were two hypural bones formed on the coccyx part. On the anal fin, there were one spiny ray and 8 soft rays shown while one spiny ray and 5 soft rays were present on the stems of ventral fin. Teethes were formed on the dentary bone of lower jaw but the air bladder was degraded. The benthic life was shown and numbers of vertebrae bones were $33(13+20)$ in this period (Fig. 4E).

After 15 days from hatching, postlarvae had the total length ranging 8.26-9.16 mm (mean $8.60 \pm 0.40 \mathrm{~mm}$ ) and melanophores were disappeared on the gastrointestinal tract; approximately 8-9 spots were remained. From the end of mouth to the front of eyes, there were chromophores precipitated (Fig. 4F).

After 18 days from hatching, postlarvae represented the total length ranging $8.49-8.93 \mathrm{~mm}$ (mean $8.65 \pm 0.20 \mathrm{~mm}$ )

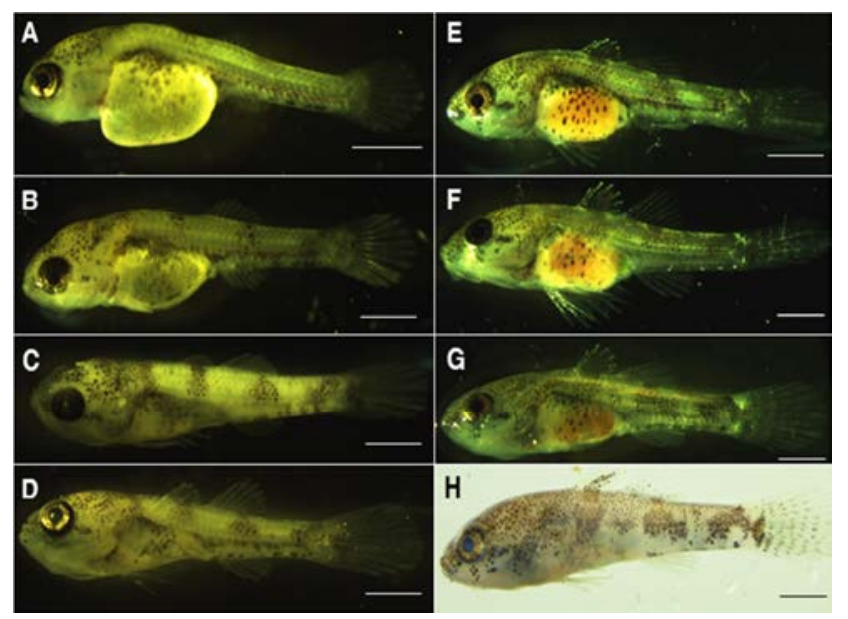

Fig. 4. The larvae and juvenile of Korean spotted sleeper, Odontobutis interrupta. A: $4.27 \mathrm{~mm}$ in total length (TL) newly hatched larvae; B: $6.20 \mathrm{~mm}$ in TL, 3 days after hatching; C: $6.43 \mathrm{~mm}$ in TL, 6 days after hatching; D: $6.69 \mathrm{~mm}$ in TL, 10 days after hatching; E: $7.11 \mathrm{~mm}$ in TL, 13 days after hatching; F: 8.60 $\mathrm{mm}$ in TL, 15 days after hatching; G: $8.65 \mathrm{~mm}$ in TL, 18 days after hatching; H: $9.71 \mathrm{~mm}$ in TL, 21 days after hatching. Scale bars $=1.0 \mathrm{~mm}$. while further melanophores were found on the first dorsal fin. These were also precipitated on the lower jaw, around eyes, as well as covers of gills (Fig. 4G).

On day 21 of hatching, the total length of postlarvae was 9.45-9.90 mm (mean $9.71 \pm 0.27 \mathrm{~mm}$ ) and melanophores were precipitated on the bottom of the first and second dorsal fins, and the middle of caudal fin. Numbers of fin rays for each fin as well as their colors were similar to those of parents (Fig. 4H).

\section{Yolk absorption throughout time}

The changes in size of yolk and total length of hatched larvae are shown in the Fig. 5. Right after the hatching, the average total length was found to be $4.27 \pm 0.35 \mathrm{~mm}$ while the size of yolk was $1.27 \pm 0.02 \mathrm{~mm}$. Thirty six hours after their hatching, the average total length and yolk size were $6.43 \pm 0.15 \mathrm{~mm}$ and $1.16 \pm 0.01 \mathrm{~mm}$, respectively. Seventy two hours later, the average total length and size of yolk were increased up to $6.69 \pm 0.14 \mathrm{~mm}$ and $1.09 \pm 0.04 \mathrm{~mm}$, respectively. After $120 \mathrm{hr}$ from hatching, the average total length of larvae was $7.11 \pm 0.26 \mathrm{~mm}$ whilst yolk was absorbed to start eating food. All yolk was completely absorbed after $120 \mathrm{hr}$ from hatching the size of yolk was getting smaller as the total length was being elongated.

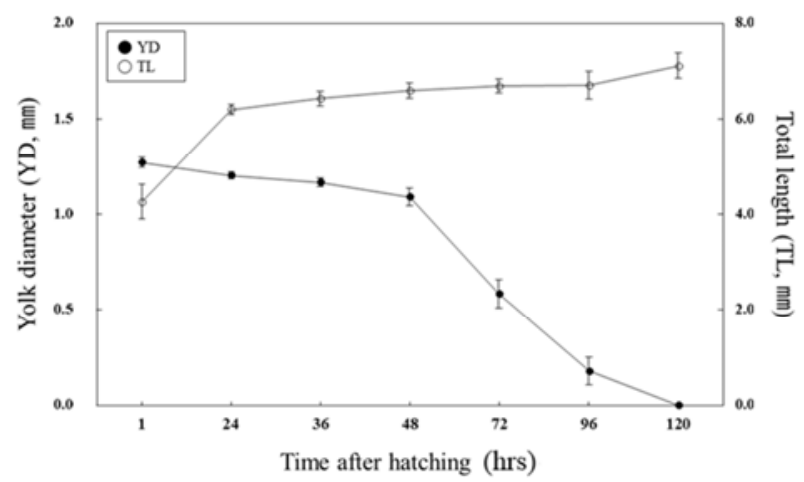

Fig. 5. Resorptions of yolk and total length of Korean spotted sleeper, Odontobutis interrupta larvae (•, YD: yolk diameter; $\circ$, TL: total length). 


\section{DISCUSSION}

The spawning season of $O$. interrupta was in between March through May which is similar to that of O. platycephala, belongs to the same family (Iwata et al., 1988), the place for spawning of O. interrupta was found to be in middle of rocky creek where gravel and sand were laid on the bottom with gentle current.

Male fishes were protecting eggs while providing oxygen, in contrast, perished eggs were discarded by these fishes as well which is very similar behaviors shown in other fishes such as O. platycephala, Rhinogobius brunneus, Coreoperca herzi, Liobagrus mediadiposalis and L. obesus (Choi \& Jin, 1977; Han et al., 1998; Moon et al., 2005; Choi et al., 2008; Seo et al., 2006).

Eggs of $O$. interrupta are oval shaped and sticky dermesal. The long axis diameter and short axis diameter were 4.15$4.27 \mathrm{~mm}$ (mean $4.23 \pm 0.05 \mathrm{~mm}$ ) and 1.65-1.85 mm (mean $1.72 \pm 0.10 \mathrm{~mm}$ ), respectively. When it comes to the size of eggs, it was similar to those of Choi \& $\mathrm{Na}$ (2000), reported that the long axis diameter and short axis diameter were $4.00 \mathrm{~mm}$ and $1.70 \mathrm{~mm}$. respectively. The $O$. platycephala, which belongs to the same family, had $3.40 \mathrm{~mm}$ and $2.00 \mathrm{~mm}$ of the long axis diameter and short axis diameter, respectively. In the study of Doi \& Aoyama (2006) the long axis diameter and short axis diameter of $O$. hikimius were $3.74-3.80 \mathrm{~mm}$, and 2.20-2.35 mm, respectively whilst they were shown to be 3.11-4.77 mm and 1.60-2.29 $\mathrm{mm}$ in O. obscura (Iwata et al., 1988), showing that the longer diameter was slightly shorter while the short axis diameter was longer compared to those of $O$. interrupta.

Fish eggs can be classified into either floating or demersal eggs depending upon their ecology, properties and shapes. In the study, we found that eggs of $O$. interrupta were demersal eggs attaching on the bottom of rocks that forms a layer, these properties are somewhat different compared to other fishes L. mediadiposalis and L. andersoni which lay non sticky egg clusters (Seo et al., 2006; Choi et al., 2008).
Time took for hatching O. interrupta eggs was $422 \mathrm{hr}$ and $5 \mathrm{~min}$ at $16.0^{\circ} \mathrm{C}$ of water temperature. In other study, Choi \& $\mathrm{Na}$ (2000) reported that it took $248 \mathrm{hrs}$ and $5 \mathrm{~min}$ at $25.8^{\circ} \mathrm{C}$ of water temperature while it took $312 \mathrm{hr}$ for $O$. platycephala to hatch eggs in water temperature ranging 20.0 $25.0^{\circ} \mathrm{C}$ (Choi \& Jin, 1977). In contrast, eggs of $O$. hikimius were hatched after $336 \mathrm{hr}$ at $24.5^{\circ} \mathrm{C}$ of water temperature which indicates that hatching time tends to be shortened with higher water temperature (Doi \& Aoyama, 2006).

When it comes to the total length of larvae just hatched, it was $4.27 \mathrm{~mm}$ in the present study. In the study of Choi \& $\mathrm{Na}$ (2000), it was shown to be $5.80 \mathrm{~mm}$ while Doi \& Aoyama (2006) reported that the total length of $O$. hikimius was ranging $6.04-6.11 \mathrm{~mm}$. In $O$. obscura, the total length was $5.00 \mathrm{~mm}$ whilst Perccottus glenii represented shorter total length, $5.50 \mathrm{~mm}$ (Voskoboinikova \& Pavlov, 2006). $O$. interrupta posses yolk when they were being hatched in the study, we observed that swimming ability as well as food intake activity were more pronounced in which yolk was further absorbed. When comparing the diameter of yolk of larvae right after hatching, O. interrupta had 1.27 $\mathrm{mm}$ and $O$. obscura (Iwata et al., 1988) showed 1.51-2.23 $\mathrm{mm}$ which was slightly shorter.

These diameters might be closely influenced by hatching time and water temperature. The Sora-creek where $O$. interrupta inhabit, has been being polluted by influx of pesticides in busy farming season as well as constructions around the river there by destructing habitats and lowering population. Therefore, it is warranted to establish protective measures for endangered Korean native species and to continue investigating with regards to conservation and restoration of these species.

\section{REFERENCES}

Blaxter JHS (1974) The Early Life History of Fish. Spring Verlag, Berlin. 765pp.

Choi KC, Jin CD (1977) On the spawning behavior and 
Egg Development and Early Life History of Korean Endemic Species Korean Spotted Sleeper, Odontobutis interrupta (Pisces: Odontobutidae)

the development of Korean eleotrid fish Odontobutis obscurus. Kor J Ecologi Sci 1:44-48.

Choi NH, Seo WI, Kim CC, Park CK, Heo SJ, Yoon SM, Han KH, Lee WK (2008) Spawning behavior and early life history of the Liobagrus mediadiposalis in the Korean endemic species. J Kor Fish Soc 41:478-484.

Choi SS, Na YU (2000) The spawning behavior and egg development of Odontobutis interrupta Iwata and Jeon, 1985. Kor J Envion Biol 18:323-330.

Doi T, Aoyama S (2006) Embryonic larval and juvenile morphologies of the freshwater goby Odontobutis hikimius reared in an aquarium were observed and described. Japan J Ichthyol 53:63-70.

Han KH, Park JT, Jung GH, Lee WK, Lee JY, Bang IC (1998) Spawning behavior and early life history of Korean aucha perch, Coreoperca herzi (Herzenstein). J Aquaculture 11:49-58.

Iwata A, Jeon SR, Mizuno N, Choi KC (1985) Arevision of the eleotrid goby genus Odontobutis in Japan, Korea and China. Japan J Ichthyol 31:373-388.

Iwata A, Jeon SR, Mizuno N, Choi, KC (1988) Larval development of a gobiid fish, Odontobutis obscura obscura in comparison with that of O. interrupta and of $O$. platycephala. Japan J Ichthyol 35:371-381.

Kim IS, Choi Y, Lee CL, Lee YJ, Kim BJ, Kim JH (2005) Illustrated Book of Korean Fishes. Kyo Hak Publishing, Seoul, Korea 418 pp.

Kim IS, Kim BJ (1994) Hypseleotris swinhonis (Günther) of spawning behavior and early development. Kor $\mathrm{J}$ Ichthyol 6:281 pp.

Kim IS, Kim BJ (1995) Hypseleotris swinhonis (Günther) of spawning behavior model and reproductive habit. Kor J Ichthyol 7:94-95.

Kim IS, Kim BJ (1996) Hypseleotris swinhonis of reproductive habit and early egg development. Kor J Ecos $19: 477-486$

Kim MS, Baek SH, Kim HY, Kim SY, Geong KI, Kweon
MJ, Ha BS (1998) Comparison of carotenoid pigments on Korean dark sleeper, Odontobutis platycephala and dark sleeper, Odontobutis odontobutis interrupta in the family Eleotridae. Kor J Soc Food Sci Nutr 27:813-820.

Lee JH, Han KH, Seo WI, Yoon SM, Kim CC, Hwang SY, Kim KS (2004) Ichthyofauna and fish community of Sora stream in Yeosu, Korea. Kor J Ichthyol 16:348355.

Lee WK (1998) Annual reproductive cycle and changes in plasma levels of sex steroid hormones of the female Korean dark sleeper, Odontobutis platycephala (Iwata et Jeon). J Kor Fish Soc 31:599-607.

Lee WK, Yang SW (1998) Testicular development and serum levels of gonadal steroids hormone during the annual reproductive cycle of the male Korean dark sleeper, Odontobutis platycephala (Iwata et Jeon). J Aquacultule 11:475-485.

Mashiko K (1976) Reproductive behavior of an eleotrid goby Odontobutis obscurus in aquaria. Japan J Ichthyol 23:69-78.

Meda K, Tachihara K (2005) Recruitment of amphidromous sleepers Eleotris acanthopoma, Eleotris melanosoma, and Eleotris fusca into the Teima river Okinawa island. Japan J Ichthyol 52:325-335.

Moon WK, Na YE, An KG (2005) Spawning behavior and early life history of Korea freshwater goby (Rhinogobius brunneus). Kor J Limnol 38:83-94.

Rusell FS (1976) The Eggs and Planktonic Stages of British Marine Fishes. Academic Press Inc, London, 524 pp.

Sakai H, Iwata A, Jeon SR (1993) Genetic evidence supporting the existence of three distinct species in the genus Odontobutis (Gobiidae) from Japan and Korea. Japan J Ichthyol 40:61-64.

Sakai H, Tanaka Y, Tsujii H, Iwata A, Ikeda I (1999) Distribution pattern of two genetically different groups of Odontobutis obscura in Takatsu river and its vicinity. 
Japan J Ichthyol 46:109-114.

Seo WI, Han KH, Yoon SM, Kim CC, Hwang SY, Lee SH, Lee CL, Son YM, Kim IS (2006) Early life history of the Liobagrus obesus (Pisces, Amblycipitidae). Dev Reprod 10:41-45.
Voskoboinikova OS, Pavlov DA (2006) Larval development of the Amur sleeper Perccottus glenii (Perciforms, Gobioidei, Odontobutidae) and the origin of fish of the suborder Gobioidei. J Ichthyol 46:826-841. 